\title{
Pemberdayaan Organisasi Intra Azzainiyah pada Pemeliharaan Taman di Lingkungan Pondok Pesantren
}

\author{
Wiwin Warliah ${ }^{1 *}$, Muliatin Nlikmah², Laili Fitriyah ${ }^{3}$
}

Universitas Nurul Jadid, Paiton ${ }^{123}$

\begin{tabular}{l}
\hline Submission: 20/12 \\
\hline Katakunci: \\
Pemberdayaan \\
Organisasi, \\
Pemeliharaan \\
Taman
\end{tabular}

Abstrak. Pemberdayaan Organisasi Intra Azzainiyah terhadap kesadaran pada pemeliharaan taman khususnya di pemondokan dalbar Pondok Pesantren Nurul Jadid. Program kelompok fisik yaitu Pemeliharaan taman yang diadakan tiap jumat pagi, sedangkan program kelompok non fisik yaitu Mengadakan Pelatihan perawatan dan pemeliharaan taman dengan mendatangkan narasumber yang pakar dibidang perawatan taman dan tanamna tujuannya agar santri khususnya oriza memiliki bekal pengetahuan dalam perlakuan terhadap tanah dan tanaman, program kegiatan tambahan motivasi berupa pemberian alat-alat berkebun berupa cangkul tangan, pot, cerek untuk siram tanaman, rumput hias. Teknik pengumpulan data dilakukan secara penelitian kualitatif lebih menekankan makna dari pada generalisasi. Sumber data dalam penelitian ini adalah Penanggung Jawab organiasasi Intra Azzainiyah, Pengurus organisasi Intra Azzainiyah, Santri-santri pondok pesantren. Data pendukung lainnya berwujud data dokumentasi atau data laporan yang telah tersedia. Sebagai data peneliti mengambil dari buku referensi atau dokumentasi yang berhubungan dengan penelitian ini. Pelaksanaan pengelolaan Taman dapat berjalan dengan baik telah di bagi rangkaian tugas atau pekerjaan yang terdapat dalam manajemen, sebagai berikut Perencanaan (Planning) Perencanaan merupakan langkah awal kegiatan menetapkan tujuan yang akan dicapai beserta cara-cara untuk mencapainya. Pengorganisasian (Organizing) Dalam pengelolaan taman dibutuhkan suatu langkah pengorganisasian agar pelaksanaan perawatan dan pemeliharaan taman dapat berjalan sesuai dengan tujuan yang telah di tetapkan bersama untuk memberikan fasilitas publik yang nyaman bagi masyarakat. Pelaksanaan (Actuating) Merupakan usaha menggerakkan anggotaanggota organisasi sedemikian rupa hingga mereka berkeinginan dan berusaha untuk mencapai sasaran atau tujuan. Dan pengawasan (Controlling) Pengawasan pada hakekatnya merupakan tindakan membandingkan antara hasil dan kenyataan dengan hasil yang diinginkan.

\section{Pendahuluan}

Mahasiswa mempunyai peran stategis sebagai agent of change. Kuliah kerja nyata (KKN) adalah satu wujud pengabdian mahasiswa perguruan tinggi kepada masyarkat lewat pemberian bantuan pemberdayaan, pelatihan, penyuluhan, pembimbingan, pendampingan dan untuk menyadarkan potensi 
yang dimiliki, serta membantu meningkatkan kualitas hidup dan pembangunan.

Mahasiswa mendapatkan kemampuan generative berupa life skills (keterampilan hidup) Observasi dilakukan dengan metode: (1) Silaturahmi, (2) Tanya jawab, (3) Dokumentasi, dan (4) Melihat kelapangan secara langsung. Berdasarkan hasil observasi maka ditentukan program kerja KKN kelompok yang akan dilaksanakan meliputi program kelompok fisik, program kelompok non fisik, program tambahan, serta program unggulan yang dapat dilaksanakan diwilayah pemondokan tersebut dengan melihat potensi santri dan oriza di wilayah yang memiliki keleluasaan dalam merawat dan memeilhara taman.

Program kelompok fisik berupa pemeliharaan taman yang dilaksanakan tiap jumat pagi, sedangkan program kelompok non fisik yaitu mengadakan pelatihan perawatan dan pemeliharaan taman. dengan mendatangkan pakar bidang perawatan taman dan tanaman tujuan agar santri khususnya oriza memiliki pengetahuan dalam perlakuan terhadap tanah dan tanaman. Program kegiatan tambahan motivasi berupa pemberian alat-alat berkebun berupa cangkul tangan, pot, ceret dan rumput hias.

Dari kegiatan tersebut, mahasiswi berperan sebagai fasilitator, dinamisator dan motivator. Secara keseluruhan program kerja terlaksanakan sesuai perencanaan. Anggota Organisasi melibatkan santri makin pro aktif terhadap kegiatan perawata tanaman. Dengan demikian setelah kegiatan KKN berakhir diharapkan ssntri maupun anggota oriza memiliki kepedulian serta tanggung jawab terhadap lingkungan, membantu dan mengayomi para santri yang tidak bergabung didalamnya untuk ikut serta dalam merawat taman dan melestarikan lingkungan.

\section{Metode}

\section{Strategi pelaksanaan}

Ketersedian taman yang dimiliki tanpa adanya sumber daya manusia yang memiliki skill dan pengetahuan menyebabkan taman-taman di wilayah Azzainiyah kurang terawat, tanahnya padat kurang gembur dan tumbuh banyak rumput liar disekitar tanaman bunga. Oleh sebab itu dirumuskan strategi pelaksanaan pendampingan berupa kegiatan pelatihan dan 
pendampingan kegiatan pemeliharaan yang dilaksanakan santri dan oriza pada jumat pagi. Kegiatan pelatihan ditempuh untuk menyikapi persoalan minimnya pengetahuan dan skill anggota oriza terhadap perawatan tanah taman dan tanaman. Pelatihan diselenggarkan oleh Mahasiswi kkn dengan mendatangkan pembicara yang pakar dibidang pemeliharan taman target sasaran santri oriza. Kegiatan dilaksanakan disiang hari setelah santri oriza mengikuti kegiatan solat berjamah di sekolah, mayoritas peserta yang hadir dari anggota oriza, sebagian pengurus wilayah dan pengurus konservasi lingkungan hidup, dimana sedikitnya mereka memiliki keerikatan dan/atau bersinggungan dengan persolaan kelestarian dan keindahan lingkungan wilayah.

kegiatan pendampingan dilaksanakan melalui bantuan langsung dengan bersama-sama antara mahasiwa kkn dan oriza membantu merapihkan taman. jenis kegiatan lainya berupa motivasi dengan memberikan sejumalah peralatan berkebun kepada santri oriza.

Pemilihan kegiatan yang bertempat di wilayah Azzainiyah dengan sasaran subjek santri oriza, disebabkan kiprah oriza yang punya peran terhadap kelestarian lingkungan selain petugas $\mathrm{KLH}$. Oriza didaulat oleh wilayah mengelola taman-taman yang berada dilingkungan pondok Azzainiyah, tujuannya agar tampak asri dan terawat. Wilayah dalbar adalah salah satu wilayah keputrian yang memiliki wewenang untuk melakukan konservasi secara mandiri terhadap lingkungan. Artinya tidak melibatkan pihak dari pegawai yang bersifat tetap untuk membantu aktifitas merawat taman dan kebersihan.

Kegiatan pelaksanaan rentang di mulai bulan Maret hingga Mei 2021, diawali dengan tahap izin melalui kepala wilayah Azzaniyah, penelitian kemudian minggu selanjutnya dilakukan kunjungan dan kegiatan.

\section{Profil Wilayah Az Zainiyah Pondok Pesantren ${ }^{1}$}

Pondok Pesantren Nurul Jadid terbagi menjadi tujuh wilayah. Satu wilayah pusat untuk santri putra,kemudian wilayah selatan yang meliputi al-Lathifiyah (santri putra dan putri fokus mengkaji ilmu fiqih), al-Mawaddah (santri putri),

1 https://www.nuruljadid.net/kategori/informasi/page/2 diakses 5 Mei 2021 
Fathimatuzzahro' (santri putri), gang K (santri putra dan putri), wilayah timur yang dikenal dengan wilayah Al-Hasyimiyah, dan wilayah barat atau utara yang dikenal dengan wilayah Az-Zainiyah untuk santri putri. Wilayah AzZainiyah terletak di sebelah utara masjid jami' Nurul Jadid dan menjadi batas utara pesantren. Wilayah Az-Zainiyah merupakan wilayah putri tertua diantara wilayah putri lain yang diasuh oleh beberapa pengasuh, diantaranya KH. Moh. Zuhri Zaini, BA. selaku pengasuh pondok pesantren Nurul Jadid, Ny. Hj. Bisyaroh Suhud, Ny. Hj. Zubaida Thoha, Ny. Hj. Nuri Firdausiyah, dan Ny. Hj. Sadidah Thoha. Di bawah naungan dan asuhan beliau, Pondok Pesantren Nurul Jadid wilayah Az-Zainiyah yang awalnya hanya ditempati oleh beberapa santri dan hanya dibangun beberapa asrama kecil akhirnya berkembang pesat dan terus mengalami perkembangan yang cukup signifikan.

Dengan semakin bertambahnya kuantitas santri maka tempat, sarana dan pembinaan yang diberikanpun terus mengejardan senantiasa memaksimalkan system pembinaan agar kualitas santri kian meningkat. Melihat kualitas pembinaan dan prestasi santri yang tak pernah pupus maka terbentuklah wilayah Az-Zainiyah yang semakin luas dan melebar seperti yang kita lihat saat ini. Sejalan dengan perkembangan zaman dan berkat komitmen pesantren dalam menjalankan visi tafaqquh fid diin, maka keberadaan pondok pesantren Nurul Jadid wilayah Az-Zainiyah dari tahun ke tahun semakin berkembang, sehingga antara jumlah santri dan saranaprasarana menjadi kurang seimbang. Oleh karenanya, perlu adanya kepedulian semua pihak agar pendidikan dan pengembangan potensi anak bangsa dapat diarahkan menuju terbentuknya insan kamil.

Oriza adalah kepengurusan santri yang dibawah kepengurusan wilayah bagian KABID IV. Tugas pengurus oriza adalah membantu dan merealiasikan program-program yang ada diwilayah, khususnya di wilayah azzainiyah sendiri. Oriza adalah organisasi perdana sejak tahun 2016 yang dibentuk oleh kepala wilayah demisioner pada era kepala wilayah Az-zainiyah dijabat oleh Wahdatul Kholisoh, dimana anak-anak siswi tingkat SLTA dan SLTP yang berada di wilayah az-zainiyah. ORIZA pertama kali dibimbing langsung oleh ustadzah Mila yang merupakan sekretaris pengurus Azzainiyah yang juga sekaligus menjadi Pembina pertama di ORIZA, yamg di ketuai oleh RetnoPalupi. 
Didirikan oriza untuk mewadahi santri dalam menyalurkan bakat dalam bidang seni, karya ilmiah, sastra, jurnalistik dan sebagai wadah dalam berorganisasi khususnya bagi santri yang berada dipesantren.

Adapun kegiatan yang dilakukan yaitu : penebitan koran, papan kreasi, melaksanakan peringatan hari nasional, membantu pengurus jika dibutuhkan, mengadakan berbagai lomba disetiap hari-hari tertentu.

\section{Diskusi dan Pembahasan}

\section{Pemberdayaan}

Pemberdayaan menurut bahasa berasal dari kata daya yang berarti tenaga atau kekuatan, proses, cara, perbuatan memberdayakan. ${ }^{2}$ Dalam Al Qur'an kata daya di sebutsebagai "al-Quwwah", dalam berbagai variannya, disebut 33 kali. $^{3}$ Dalam bahasa arab disebut "al-Quwwah", dalam bahasa Inggris disebut "empower" yang menurut Cornell University Empowerment Group dalam sleeby yang dikutip oleh Hatta Abdul Malik mengatakan bahwa pemberdayaan adalah:

Suatu proses yang disengaja dan berlangsung secara terus-menerus yang dipusatkan di dalam kehidupan komunitas lokal, meliputi: salingmeng hormati, sikap refleksi kritis, adanya kepedulian dan partisipasi kelompok, yang melaluinya masyarakat yang merasa kurang memiliki secara bersama sumber-sumber yang berharga menjadi memperoleh akses yang lebih besar untuk mendapatkan dan mengontrol sumber-sumber tersebut. ${ }^{4}$

Pemberdayaan adalah upaya yang membangun daya masyarakat dengan mendorong, memotivasi dan membangkitkan kesadaran akan potensi yang dimiliki serta berupaya untuk mengembangkannya. ${ }^{5}$ Berarti mendorong mereka menjadi lebih terlibat dalam keputusan dan aktivasi yang memenuhi pekerjaan mereka. Dengan demikian, berarti memberi mereka kesempatan

\footnotetext{
2 Pusat Bahasa Departemen Pendidikan Nasional, Kamus Besar Bahasa Indonesia, (Jakarta: Balai Pustaka, 2002), hal. 242

${ }^{3}$ Muahammad Fuad al-Baqi', Mu'jam al-Mufaras al-Fad al-Quran al-Karim, t.t, DAR Alflkr, hal. 587

${ }^{4}$ Hatta Abdul Malik, Jurnal Dimas, Pemikiran Agama untuk Pemberdayaan, (Semarang: LPM IAIN Walisongo, 2012), hal. 193

${ }^{5}$ Daniel Sukalele, "Pemberdayaan Masyarakat Miskin di Era Otonomi Daerah", diakses pada tanggal 17April 2021
} 
untuk menunjukkan bahwa mereka dapat memberikan gagasan baik dan mempunyai ketrampilan mewujudakan gagasannya menjadi realitas.

Pemberdayaan merupakan perubahan yang terjadi pada falsafah manajemen yang dapat membantu menciptakan suatu lingkungan dimana setiap individu dapat menggunakan kemampuan dan energinya untuk meraih tujuan organisasi. Seorang karyawan memiliki wewenang dan berinisiatif untuk melakukan sesuatu yang dipandang perlu, jauh melebihi tugasnya sehari-hari.

Robbins yang dikutip pada buku "Manajemen Kinerja" mengungkapkan pemberdayaan sebagai menempatkan pekerja bertanggungjawab atas apa yang mereka kerjakan. Dengan demikian, manajer belajar untuk berhenti mengontrol dan pekerja belajar bagaimana bertanggung jawab atas pekerjaannya dan membuat keputusan yang tepat. Pemberdayaan dapat mengubah gaya kepemimpinan, hubungan kekuasaan, cara pekerjaan dirancang, dan cara organisasi distrukturkan. ${ }^{6}$

Pemberdayaan merupakan suatu proses dimana pekerja diberi peningkatan sejumlah otonomi dan keleluasan dalam hubungannya dengan pekerjaan mereka. Pemberdayaan merupakan kontinum antara keadaan pekerja yang tidak mempunyai kekuatan untuk mempertimbangkan bagaimana mengerjakan pekerjaan, sampai pada keadaan di mana pekerja memiliki control sepenuhnya atas apa yang mereka kerjakan dan bagaimana mengerjakannya. Dengan pemberdayaan, telah terjadi pergeseran kekuasaan kepada timpekerja yang diperbolehkan membuat keputusan sendiri.

Sementara itu, Newstrom dan Davis yang dikutip pada buku "Manajemen Kinerja" juga mengungkapkan Pemberdayaan Merupakan setiap proses yang memberikan otonomi yang lebih besar kepada pekerja melalui saling menukar informasi yang relevan dan ketentuan tentang pengawasan atas faktor-faktor yang memperngaruhi prestasi kerja. Maka, pemberdayaan merupakan suatu proses untuk menjadikan orang menjadi lebih terberdaya atau lebih berkemampuan untuk menyelesaikan masalahnya sendiri, dengan cara memberikan kepercayaan dan kewenangan sehingga menumbuhkan rasa tanggung jawabnya. Pemberdayaan dapat mendorong orang untuk lebih terlibat dalam pembuatan keputusan dalam organisasi. Dengan demikian,

${ }^{6}$ Wibowo, Manajemen Kinerja, (Jakarta:PT Raja Grafindo Persada, 2016), hal340 
akan meningkatkan kemampuan dan rasa memiliki, dan meningkatkan rasa tanggung jawab sehingga kinerjanya meningkat. Pekerja yang diberdayakan diharapkan melakukan pekrjaan melebihi tanggung jawab yang diberikan kepada meraka. ${ }^{7}$

Pemberdayaan yaitu aspek pembangunan, hakikat pembangunan nasional adalah pembangunan manusia seutuhnya dan masyarakat seutuhnya, dengan kata lain memberdayakan masyarakat mengandung makna mengembangkan, memandirikan, menswadayakan, dan memperkuat posisi tawar menawar masyarakat lapisan bawah terhadap kekuatan-kekuatan penekanan di segalabidang dan sektor kehidupan. Disamping itu, juga mengandung arti melindungi dan membela dengan berpihak pada yang lemah, untuk mencegah terjadinya persaingan yang tidak seimbang dan eksploitasiatas yang lemah. ${ }^{8}$ Pentingnya pembangunan masyarakat menitikberatkan sektor ekonomi ialah agar masyarakat dapat meningkatkan kesejahteraan penduduk melalui pertumbuhan sektor ini, tanpa mengabaikan peranan sektor-sektor lainnya, dan sekaligus dapat menurunkan tingkat kemiskinan penduduk. ${ }^{9}$

Disimpulkan bahwa konsep dasar pemberdayaan pada dasarnya yaitu upaya suatu kelompok masyarakat untuk meningkatkan kemampuan dan kemandirian sehingga masyarakat dapat mengaktualisasikan potensi yang sudah dimiliki dalam rangka tujuan hidup yang lebih sejahtera. Pemberdayaan yang diinginkan oleh masyarakat adalah pemberdayaan yang bisa membangun masyarakat kearah yang lebih sesuai dengan tujuan pemberdayaan.

Usaha memberdayakan masyarakat desa serta menanggulangi kemiskinan dan kesenjangan menjadi fenomena yang semakin kompleks, pembangunan pedesaan dalam perkembangannya tidak semata-mata terbatas pada peningkatan produksi pertanian. Pembangunan pedesaan juga tidak hanya cukup implementasi program peningkatan kesejahteraan sosial melalui distribusi uang dan jasa untuk mencukupi kebutuhan dasar. Lebih dari itu adalah sebuah upaya dengan spektrum kegiatan yang menyentuh pemenuhan berbagai kebutuhan sehingga masyarakat dapat mandiri,

\footnotetext{
${ }^{7}$ Ibid, Hal. 349

${ }^{8}$ Onny. S. Prijiono, Pemberdayaan, Konsep, Kebijakan dan Implementasinya, (Jakarta: CSIS, 1996), hal. 97

${ }^{9}$ Sudjana, Pendidikan Luar Sekolah, (Bandung: Falah Production, 2001), hal, 256
} 
percayadiri, dan tidak bergantung dan dapat lepas dari belenggustruktural yang membuat hidup sengsara. ${ }^{10}$

\section{Pemberdayaan Organisasi}

Apabila suatu oraganisasi menjalankan pemberdayaan, dikalangan anggota organisasi akan tumbuh perasaan dikalangan anggota organisasi akan tumbuh perasaan menjadi bagian kelompok. Tumbuh perasaan puas dalam mengambil tanggung jawab untuk mejalankan tugasnya. Terdapat perasaan bahwa mereka telah melakukan sesuatu yang berharga dan memperoleh kesenangan dalam melakukan komunikasi dan kerjasama dengan orang lain.dengan demikian, pemberdayaan menigkatkan percaya diri dalam melakukan sesuatu. Akibatnya akan terjadi peningkatan kepuasan kerja, kerjasama yag lebih dekat dengan orang lain, bekerja dengan tujuan yang lebih jelas, dan mendapatkan prestasi apabila tujuan tercapai.

Bagi organisasi, pemberdayaan meningkatkan kinerja organsiasi dan inividu yang dapat mengembangkan bakatnya secara penuh. Departemen atau tim menjadi lebih antusias, aktif dan sukses. Anggota menguasai pemahaman dan keterampilan baru dan engan member kesempatan melihat sesuatu dengan cara berbeda, mereflesikan apa yang dilihat dan mengembangkan keterampilan baru. Sementara itu, pimpian terdorong untuk bekerja lebih keras, disamping harus mengerjakan pekerjaan rutin, yaitu berhadapan dengan masalah krisis dalam memberdayakan anggotanya. ${ }^{11}$

Pemberdayaan organisasi adalah proses pemberian daya atau kekuatan (power) terhadap perilaku dan potensi individu atau masyarakat, serta pengorganisasian kelompok masyarakat oleh pemerintah maupun masyarakat itu sendiri atas dasar partisipasi. Pemberdayaan tersebut bertujuan agar masyarakat dapat memiliki inisiatif untuk melaksanakan berbagai kegiatan-kegiatan sosial kemasyarakatan di sekitarnya agar dapat memperbaiki atau meningkatkan kualitas serta kondisi diri sendiri menjadi lebih baik. Pemberdayaan memiliki tujuan untuk membuat masyarakat

\footnotetext{
${ }^{10}$ Sunyoto Usman, Pembangunan dan Pemberdayaan Masyarakat, (Yogyakarta: Pustaka Pelajar, 2010), hal. 31

${ }^{11}$ Suparjan, Pengembangan Masyarakat dari Pembangunan samapai

Pemberdayaan,(Yogyakarta:Aditya Media, 2003). Hal. 353
} 
menjadi mandiri, dan dapat memperbaiki segala aspek, dalam arti memiliki potensi agar mampu menyelesaikan masalah-masalah yang mereka hadapi dan sanggup memenuhi kebutuhannya dengan tidak menggantungkan hidup mereka pada bantuan pihak luar baik pemerintah maupun non pemerintah.

\section{Pemeliharaan Taman}

\section{a. Pemeliharaan Taman}

Usaha manusia dalam mengubah, mengatur dan menata ekosistem/lanskap agar manusia memperoleh manfaat yang maksimal dengan mengusahakan kontinuitas produksinya/keberadaannya. ${ }^{12}$

\section{1) Hakikat Pemeliharaan Taman}

Baik buruknya pelaksanaan pengelolaan atau pemeliharaan akan sangat menentukan tingkat keberhasilan suatu keberlanjutan karya lanskap (taman). Tahap pengelolaan taman seringkali menjadi anak tiri atau dinomor-duakan dalam keseluruhan proses merencana-merancang melaksana. ${ }^{13}$

2) Tujuan pemeliharaan Taman

Tujuan umum pengelola taman antara lain : $:^{14}$

a) Areal taman hendaknya selalu dijaga kebersihannya setiap waktu.

b) Areal taman dan segala fasilitasnya dirawat agar dapat digunakan secaraoptimal dan tampak indah.

c) Areal taman dan fasiltasnya dipelihara untuk menciptakan lingkungan yang sehat.

3) Prinsip Pemeliharaan Taman

a) Dalam prinsip pemeliharaan taman organisasi sebagai berikut: 15

b) Menetapkan tujuan dan standar pemeliharaan

c) Pemeliharaan harus mencerminkan penggunaan waktu, tenaga, alat dan bahan secara ekonomis

\footnotetext{
${ }^{12}$ http://kaswanto.staff.ipb.ac.id/files/2017/12/MG-12-Pengelolaan-dan-PemeliharaanTaman-ARL200-2017.pdf diakses pada 5 April 2021

${ }^{13}$ http://hsarifin.staff.ipb.ac.id/2019/08/18/2019-dasar-dasar-arsitektur-lanskapfundamental-of-landscape-architecture/ diakses pada 5 April 2021

${ }^{14}$ H.S. Arifin. 2005. Pemeliharaan Taman. Jakarta: Penebar Swadaya. Hal 16

${ }^{15} /$ bid, http://hsarifin.staff.ipb.ac.id/2019/08/18/2019-dasar-dasar-arsitektur-lanskapfundamental-of-landscape-architecture/ diakses pada 5 April 2021
} 
d) Pelaksanaan pemeliharaan didasarkan pada perencanaan pemeliharaan tertulis

e) Jadwal pekerjaan pemeliharaan didasarkan pada pertimbangan prioritas dan kebijakan

f) Seluruh bagian pemeliharaan hendaknya menekankan pada pemeliharaan pencegahan (preventive maintenance)

g) Bagian/divisi pemeliharaan harus dikelola/dimanage dengan baik

h) Institusi/Dinas pertamanan hendaknya menyediakan sumberdaya dana yang cukup untuk mendukung program pemeliharaan

i) Institusi/Dinas pertamanan hendaknya menyediakan tenaga kerja yang cukup untuk melaksanakan fungsi pemeliharaan

j) Program pemeliharaan hendaknya dirancang untuk melindungi lingkungan alami

k) Bagian/Divisi pemeliharaan harus bertanggung jawab dalam keamanan pegawai serta masyarakat

I) Pemeliharaan harus menjadi pertimbangan utama dalam perancangan dan pembangunan taman dan fasilitasnya.

m) Pegawai bagian pemeliharaan bertanggung awab bagi pencitraan masyarakat terhadap dinas pertamanan

4) Fasilitator Pemeliharaan Taman ${ }^{16}$

a) Sumber dana yang cukup dapat mendukung program pemeliharaan yang telah ditetapkan.

Biaya pemeliharaan merupakan penggerak utama untuk kelancaran pekerjaan. Saat ini, sebagian besar orang masih beranggapan yang penting adalah membangun lebih dahulu, sedangkan pemeliharaan adalah urusan belakangan, hal ini menyebabkan banyak pemilik taman tidak menganggarkan biaya pemeliharaan. Akibatnya banyak taman yang dibangun dengan biaya mahal, tetapi tidak terawat dengan baik.

\footnotetext{
${ }^{16}$ http://sibima.pu.go.id/pluginfile.php/32532/mod_resource/content/1/2005-11

Pemeliharaan\%20Taman.pdf diakses 5 April 2021
} 
b) Menyediaan tenaga kerja yang cukup, sangat penting untuk melaksanakan fungsifungsi pemeliharaan.

Tenaga kerja dapat terdiri dari tenaga kerja tetap dan tenaga kerja harian. Tenaga kerja hendaknya orang yang menguasai penggunaan peralatan dan pemeliharaan peralatan.

c) Program pengelolaan harus dirancang untuk melindungi lingkungan alam

Di daerah perkotaan yang memiliki sedikit ruang terbuka hijau, kehadiran taman baik taman rumah, taman perkantoran, taman bermain anak-anak di sekolah, taman perkotaan, maupun taman jalur hijau sangat berarti bagi perlindungan lingkungan hidup manusia, tumbuhan dan satwa liar.

d) Pengelolaan pemeliharaan taman harus bertanggung jawab terhadap keamanan umum dan para operator pemelihara taman.

Adanya tanggung jawab pengelola akan memberikan jaminan kenyamanan pengguna taman dan ketenangan bekerja bagi para operator pemelihara taman. Oleh karena itu, pemantauan terhadap elemen-elemen taman dan fasilitasnya harus dilakukan secara rutin sehingga tidak membahayakan pengunjung. Keselamatan dan keamanan operator pemelihara taman dapat siusahakan dengan cara memberikan fasilitas alat bantu yang cukup.

e) Pemeliharaan dijadikan pertimbanagan utama dalam perancangan dan pembangunan taman.

Bahan dan fasilitas yang digunakan hendaknya tahan lama, mudah dipelihara, mudah diperbaki, dan mudah diganti. Selain itu juga perlu pertimbangan lain, seperti segi estetika, keamanan, biaya, dan fungsi.

f) Para operator pemelihara harus bertanggung jawab terhadap terhadap pengelola pemelihara taman.

Masyaarakat pengguna taman akan memberikan penghargaan yang baik terhadap pengelola taman bila taman yang ada dapat memenuhi fungsinya secara optimal. Kondisi tersebut sebenarnya tanggung jawab operator pemelhara taman. Baik buruknya hasil pekerjaan para operator pemelihara taman akan memberikan dampak positif/negatif bagi citra badan pengelola tersebut dimata masyarakat pengguna taman. 


\section{Pemberdayaan Organisasi Terhadap Pemeliharaan Taman}

Manajemen adalah suatu rangkaian pekerjaan atau usaha yang dilakukan oleh sekelomok orang untuk melakukan serangkaian pekerjaan dalam mencapai tujuan tertentu, agar pelaksanaan pengelolaan taman dapat berjalan dengan baik. Telah dibagi tugas atau pekerjaan yang terdapat dalam manajemen tersebut, sebagai berikut.

1. Perencanaan (Planning)

Perencanaan merupakan Langkah awal kegiatan menetapkan tujuan yang akan dicapai beserta cara-cara untuk mencapainya. Tanpa perencanaan yang baik, maka kegiatan organisasi mengalami hambatan. Perencanaan yang baik memberikan manfaat yaitu mengembangkan langkah-langkah strategis, sebagai pedoman dalam pelaksanaan kegiatan, mengidentifikasi dan menghidari permasalahan yang timbul dimasa yang akan datang, dan dapat dengan mudah melakukan pengawasan.

2. Pengorganisasian (Organizing)

Dalam pengelolaan taman dibutuhkan suatu Langkah pengorganisasian agar pelaksanaan perawatan dan pemeliharaan taman dapat berjalan sesuai dengan tujuan yang telah ditetapkan Bersama untuk memberikan fasilitas publik yang nyaman bagi masyarakat. Pengorganisasian merupakan proses penyusunan struktur organisasi yang sesuai dengan tujuan, sumberdaya organisasi, dan lingkungan organisasi berada. Pengorganisasian bertujuan membagi suatu kegiatan yang besar menjadi kegiatankegiatan yang lebih kecil. Selain itu mempermudah dilakukannya pengawasan dan menentukan orang yang di butuhkan untuk melaksanakan tugas-tugas yang telah di tentukan. 
a. Pelaksanaan (Actuating)

Merupakan usaha menggerakkan anggota-anggota organisasi sedemikian rupa hingga mereka berkeinginan dan berusaha untuk mencapai sasaran atau tujuan. Pelaksanaan merupakan upaya untuk menjadikan perencanaan menjadi kenyataan, dengan melalui berbagai pengarahan dan pemotivasi agar setiap karyawan dapat melaksanakan kegiatan secara optimal sesuai peran, tugas, dan tanggungjawabnya. Pelaksanaan yang dilakukan oleh Organisasi Intra Azzainiyah Terhadap Pemeliharaan Taman di Pondok Nurul Jadid berupa penyapuan, penataan tanaman dan pemeliharaan fasilitas yang ada pada taman.

b. Pengawasan (Controlling)

Pengawasan pada hakekatnya merupakan Tindakan membandingkan antara hasil dan kenyataan dengan hasil yang diinginkan. Pengawasan mengukur pelaksanaan dengan tujuan menentukan sebab-sebab penyimpangan dan mengambil Tindakan korektif sehingga hasil pekerjaan sesuai dengan perencanaan. Pengawasan dikatakan penting karena tanpa adanya pengawasan yang baik tentunya akan menghasilkan tujuan yang kurang memuaskan, baik bagi organisasi maupun para pekerjanya. Dalam hal ini, kegiatan monitoring sebagai bagian dari pengawasan dilakukan terhadap jalannya pelaksanaan perawatan maupun pemeliharaan taman yang dilakukan oleh penanggungjawab organisasi yang berwenang.

\section{Faktor-faktor yang Mempengaruhi Pengelolaan Taman}

Pengelolaan yang dilakukan oleh Organisasi Intra Azzainiyah belum mencapai hasil yang maksimal. Pemeliharaan ataupun perawatan untuk fasilitas taman masih sangat perlu perhatian dari pihak pengelola. Beberapa fasilitas masih belum terpenuhi dari revitalisasi taman kota yang telah di rencanakan dari tahun 2021 lalu. Hal tersebut menyebabkan kurangnya kenyamanan bagi pengunjung atau masyarakat yang datang untuk menikmati fasilitas publik di Pondok Nurul Jadid. Adapun faktor-faktor yang 
menghambat dalam pengelolaan taman Organisasi Intra Azzainiyah adalahsebagaiberikut:

a. Anggaran

Anggaran merupakan alat untuk membantu manajemen dalam pelaksanaan, fungsi perencanaan, koordinasi, pengawasan dan juga sebagai pedoman kerja dalam menjalankan kegiatan untuk tujuan yang telah ditetapkan. ${ }^{17}$ Anggaran atau pendanaan faktor yang sangat penting dalam pengelolaan taman. Dalam mewujudkan hal ini Organisasi Intra Azzainiyah memperoleh dana yang bersumber dari lembaga pendidikan terkait. Anggaran tersebut digunakan untuk revitalisasi taman dalam pemeliharaan dan perawatan fasilitas yang ada. Namun anggaran yang telah disediakan belum mencukupi untuk revitalisasi taman ini.

b. KarakterPemanfaat (warga sekitar pondok)

Yang dimaksud karakter masyarakat dalam hal ini adalah pengetahuan dan kepedulian masyarakat terhadap manfaat dan fungsi taman ini sebagai ruang publik. Pengetahuan bagaimana taman ini dimanfaatkan sebagai ruang publik yang digunakan untuk bersantai dan berkumpul dengan orang terdekat di luar rumahs ecara gratis dan bernuansa alam. Kepedulian berupa partisipasi masyarakat untuk menjaga taman seperti tidak membuang sampah sembarangan dan tidak merusak fasilitas yang ada. Karena taman dibangun sebagai ruang publik untuk memenuhi kebutuhan masyarakat akan ruangt erbuka hijau pada lingkungan sekitar.

\section{Pengertian Taman}

Taman dalam pengertian terbatas merupakan sebidang lahan yang ditata sedemikian rupa sehingga mempunyai keindahan dan kenyamanan, dan keamanan bagi pemilik atau penggunanya. Berdasarkan skala dan bentuknya, taman dapat disebut garden, park, atau landscape. Pengembalian fungsi ruang terbuka hijau yang dilakukan oleh Dinas Kebersihan dan Pertamanan Kota Pekanbaru, selain memaksimalkan tiap jengkal tanah kosong juga

17 Arfan Ikhsan. 2008. Akuntansi Lingkungan \& Pengungkapannya. Yogyakarta: Graha Ilmu. Hal 68 
menghiasnya dengan tanaman dengan bunga warna-warni yang tidak saja cantik tapi juga fungsional. Tanaman dan bunga yang menghias jalan-jalan kota dipilih bukan hanya karena bentuknya yang indah. Tapi bunga dan tanaman itu memang memiliki fungsi ganda, indah untuk kecantikan kota sekaligus mereduksi pencemaran udara untuk Kesehatan warga kota.

Ruang terbuka seperti taman kota merupakan wadah yang menampung aktivitas manusia dalam suatu lingkungan yang tidak mempunyai penutup dalam bentuk fisik dan tidak dapat dipisahkan dari manusia baik secara psikologis,emosional atau pun dimensional. Menurut Mulyandari mengungkapkan fungsi ruang terbuka sebagai berikut: ${ }^{18}$ Umum: tempat berolahraga, main, santai, komunikasi sosial, menunggu, sarana penghubung suatu tempat dengan tempat lain pembatas. Psikologis: penyerapan udara, penyerapan air hujan, pengendali banjir, memelihara ekosistem tertentu, pelembut arsitektur bangunan. Konsep taman kota yang di kembangkan oleh Howard dalam Adisasmita pada dasarnya berpegang pada tiga prinsip dasar yaitu: ${ }^{19}$ Lahan dikuasai atau di kendalikan oleh pemerintah, di desain dengan cermat yang lengkap dengan unsur-unsur kotanya.

\section{Gambaran kegiatan}

Kegiatan pemberdayaan organisasi intra azzainiyah terhadap pemeliharaan taman oleh mahasiswi kkn yakni melalui Program kelompok fisik yaitu Pemeliharaan taman yang diadakan tiap jumat pagi, sedangkan program kelompok non fisik yaitu Mengadakan Pelatihan perawatan dan pemeliharaan taman dengan mendatangkan narasumber yang pakar dibidang perawatan taman dan tanamna, program kegiatan tambahan motivasi berupa pemberian alat-alat berkebun berupa cangkul tangan, pot, cerek untuk siram tanaman, rumput hias.

\section{Manfaat kegiatan}

Agar anggota organisasi intra az-zainiyah memiliki pengetahuan dan kepedulian dalam merawat tanah dan tanaman ditanam az-zainiyah,

\footnotetext{
${ }^{18}$ HestinMulyandari 2011. Pengantar Arsitektur Kota. Yogyakarta: Andi Offset. Hal. 190

${ }^{19}$ Rahardjo Adisasmita. 2006. Pembangunan Pedesaan dan Perkotaan. Yogyakarta: Graha Ilmu. Hal. 142
} 
mendorong santri untuk meningkatkan kepedulian terhadap keindahan dan kebersihan taman az-zainiyah

Waktu pelaksanaan kegiatan

kegiatan pelatihan dilaksanakan tanggal 30 januari 2021, waktu menyesuaikan dengan jadwal santri, yakni sepulang dari sekolah jam 13.00 hingga 14.30 bertempat dipendopo Az-Zainiyah. durasi kegiatan berlangsung 120 menit, sesi awal dalam 90 menit berupa pematerian teori dan 30 menit praktik lapangan. Kegiatan pendampingan pemeliharaan tanam dilaksanakan pada hari jumat pagi

\section{Materi pelatihan}

Perawatan Dan Pemeliharaan Tanaman

\section{Pembersihan Taman}

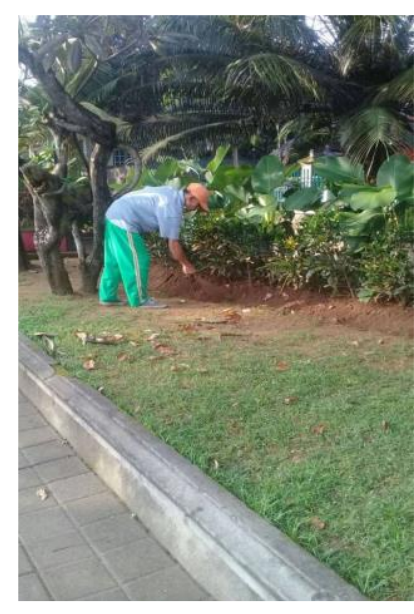

Pembersihan taman adalah upaya agar daerah sekitar taman selalu dalam kondisi yang bersih dari sampah-sampah, baik itu sampah sisa tanaman ataupun sampah non tanaman (kertas, plastikplastik pembungkus, batu, dll). Ada masanya beberapa jenis tanaman akan menggugurkan daunnya karena musim, atau ada tanaman yang karena usia daun akan menguning lalu gugur. Atau pembersihan yang di lakukan setelah pemangkasan tanaman atau pemotongan rumput, di mana sisa tanaman tersebut harus segera di bersihkan dari lokasi taman. Pekerjaan pembersihan lahan rutin di lakukan setiap hari pada sekitar taman, hal ini biasanya di lakukan dengan penyapuan lahan pada pagi hari atau sore hari.

Pemangkasan

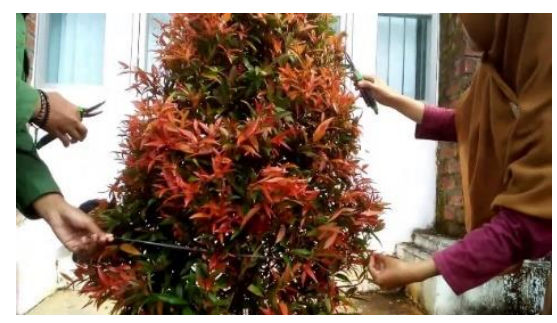

Pemangkasan adalah Penghilangan beberapa bagian tanaman.Tujuan dari pemangkasan adalah untuk membentuk tanaman dengan cara mengontrol atau 
mengarahkan pertumbuhan tanaman, untuk menjaga kesehatan tanaman, atau untuk meningkatkan hasil atau kualitas buah atau bunga yang dihasilkan.

\section{Pendangiran}

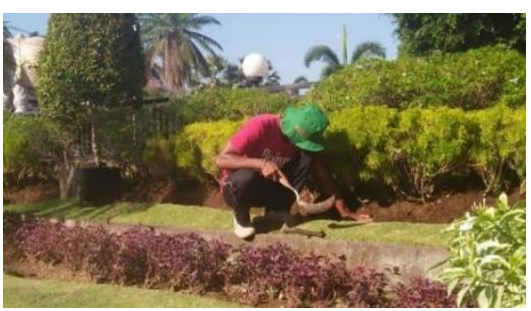

Penyiangan

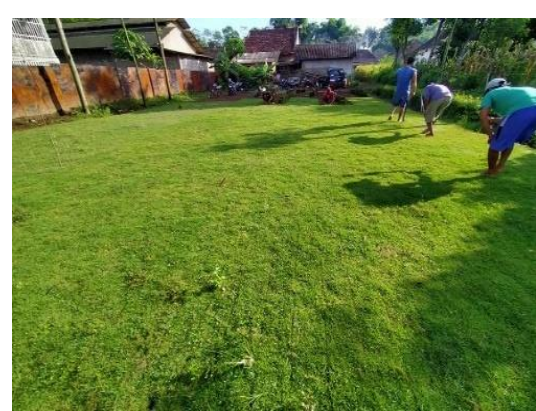

Penyiraman

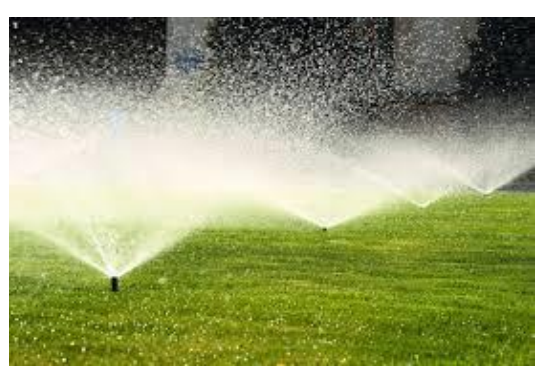

Kegiatan ini adalah menggemburkan daerah sekitar tanaman agar oksigen dapat masuk ke dalam tanah (aerasi) sehingga memudahkan akar dalam penyerapan unsur hara dalam tanah.

Penyiangan adalah pembersihan tanaman liar/gulma pada area sekitar tanaman. Hal ini di maksudkan agar tidak adanya persaingan dalam penyerapan unsur hara dalam tanah. Dan pada taman juga di maksudkan agar keindahan serta kerapihan taman dapat di capai secara maksimal.

Tanaman butuh di siram agar tanah tetap lembab sehingga akar-akar tanaman dapt melakukan fungsinya yaitu menyerap zat makan dari dalam tanah. Selain menjaga kelembaban tanah, pemyiraman di butuhkan tanaman untuk meluruhkan kotoran debu pada daun-daunnya. 


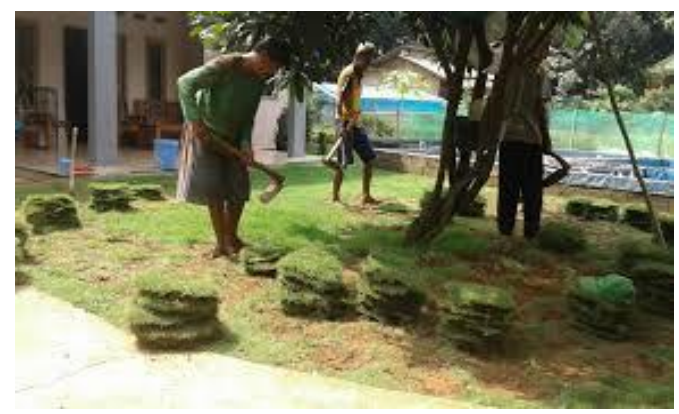

Penyulaman tanaman adalah kegiatan penanaman kembali bagian-bagian yang kosong bekas tanaman yang rusak atau mati atau diduga akan mati atau rusak atau yang kondisinya dianggap tidak sempurna.

\section{Pemupukan}

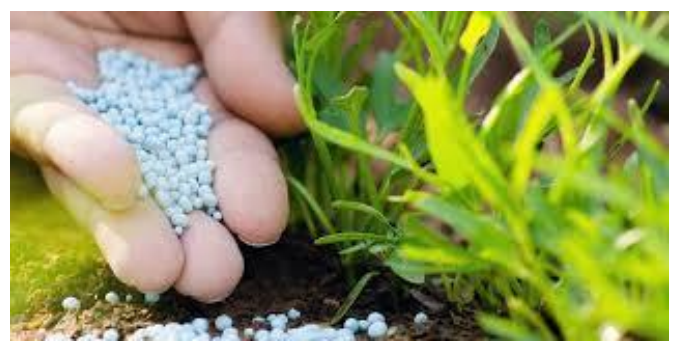

Pemupukan di tujukan untuk memperbaiki kesuburan tanah, yaitu dengan penambahan bahan ke dalam tanah atau tubuh tanaman.

\section{Pengendalian Hama Dan Penyakit}

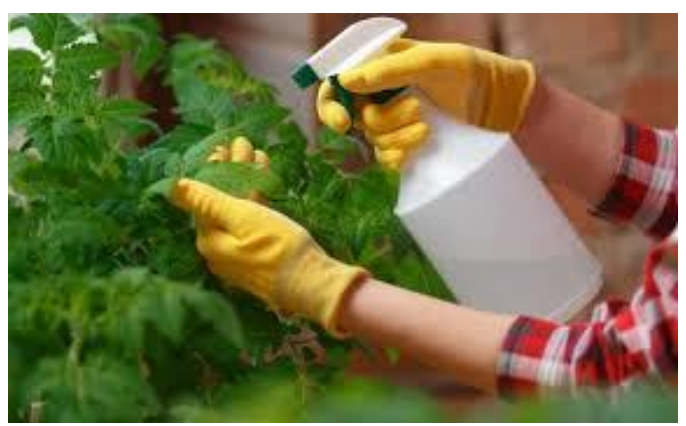

Pengendalian hama dan penyakit adalah suatu konsep atau cara berpikir dalam upaya pengendalian populasi atau tingkat serangan hama dan penyakit

\section{Metode pelaksanaan kegiatan}

kegiatan pelatihan perawatan dan pemeliharaan taman memakai metode ceramah dan Tanya jawab, kegiatan berlangsung dalam dua sesi, sesi pertama berupa pemaparan teori dan sesi kedua praktik lapangan. Kegiatan pendampingan pemeliharaan taman dilakukan dengan berpartisipasi terjun dan telibat dengan anggota oriza dalam pelaksanaan kebersihan, kerapihan dan keindahan taman 


\section{Hasil Kegiatan}

Hasil kegiatan kkn mahasiwi terhadap pemberdayaan organisasi Intera AzZainiyah terhadap pemeliharaan taman berupa pelatihan perawatan dan pemeliharaan taman serta kegiatan pendampingan dan motivasi, kebersihan taman menjadi lebih terjaga, keadaan tanah taman yang berada di lingkungan menjadi lebih gembur, tanaman mendapat kecukupan air, lingkungan pondok jadi lebih hijau.

\section{Dinamika kegiatan}

Melahirkan motivasi terhadap anggota oriza untuk lebih giat dalam menjalankan peran organisasi dalam pembantu wilayah khususnya untuk kegiatan lingkungan, anggota organisasi intera Az-zainiyah memiliki semangat dan peran dalam menjaga kebersihan dan keindalam taman, santri ikut perbartisipasi dalam merawat dan menjaga lingkungan taman.

\section{Teori dihasilkan dari kegiatan pendampingan}

Agar pelaksanaan pengelolaan Taman dapat berjalan dengan baik telah di bagi rangkaian tugas atau pekerjaan yang terdapat dalam manajemen, sebagai berikut :

1. Perencanaan (Planning) : Perencanaan merupakan langkah awal kegiatan menetapkan tujuan yang akan dicapai beserta cara-cara untuk mencapainya.

2. Pengorganisasian (Organizing) : Dalam pengelolaan taman dibutuhkan suatu langkah pengorganisasian agar pelaksanaan perawatan dan pemeliharaan taman dapat berjalan sesuai dengan tujuan yang telah di tetapkan bersama untuk memberikan fasilitas publik yang nyaman bagi masyarakat.

3. Pelaksanaan (Actuating) : Merupakan usaha menggerakkan anggotaanggota organisasi sedemikian rupa hingga mereka berkeinginan dan berusaha untuk mencapai sasaran atau tujuan.

4. Pengawasan (Controlling): Pengawasan pada hakekatnya merupakan tindakan membandingkan antara hasil dan kenyataan dengan hasil yang diinginkan. 


\section{Kesimpulan}

Pengelolaan yang dilakukan oleh Organisasi Intra Azzainiyah belum mencapai hasil yang maksimal. Pemeliharaan ataupun perawatan untuk fasilitas taman masih sangat perlu perhatian dari pihak pengelola. Beberapa fasilitas masih belum terpenuhi dari revitalisasi taman kota yang telah di rencanakan dari tahun 2021 lalu. Hal tersebut menyebabkan kurangnya kenyamanan bagi pengunjung atau masyarakat yang datang untuk menikmati fasilitas publik di Pondok Nurul Jadid. Adapun faktor-faktor yang menghambat dalam pengelolaan taman Organisasi Intra Azzainiyah adalah sebagai berikut:

1. Anggaran: Dalam mewujudkan hal ini Organisasi Intra Azzainiyah memperoleh dana yang bersumber dari lembaga pendidikan terkait. Anggaran tersebut di gunakan untuk revitalisasi taman dalam pemeliharaan dan perawatan fasilitas yang ada. Namun anggaran yang telah disediakan belum mencukupi untuk revitalisasi taman ini.

2. Karakter Pemanfaat (warga sekitar pondok): Kepedulian berupa partisipasi masyarakat untuk menjaga taman seperti tidak membuang sampah sembarangan dan tidak merusak fasilitas yang ada. Karena taman dibangun sebagai ruang publik untuk memenuhi kebutuhan masyarakat akan ruang terbuka hijau pada lingkunga nsekitar.

\section{Daftar Pustaka}

Arfan Ikhsan. 2008. Akuntansi Lingkungan \& Pengungkapannya. Yogyakarta: Graha IImu.

Dokumen Organisasi Intra Azzainiyah diberikan pada bulan 5 April 2021

H.S. Arifin. 2005. Pemeliharaan Taman. Jakarta: Penebar Swadaya.

http://hsarifin.staff.ipb.ac.id/2019/08/18/2019-dasar-dasar-arsitekturlanskap

fundamental-of-landscape-architecture/ diakses pada 5 April 2021

http://kaswanto.staff.ipb.ac.id/files/2017/12/MG-12-Pengelolaan-danPemeliharaan 
Taman-ARL200-2017.pdf diakses pada 5 April 2021

http://sibima.pu.go.id/pluginfile.php/32532/mod resource/content/1/2005 -11Pemeliharaan\%20Taman.pdf diakses 5 April 2021

https://www.nuruljadid.net/kategori/informasi/page/2 diakses 5 Mei 2021

Suparjan.2003. Pengembangan Masyarakat dari Pembangunan samapai Pemberdayaan. Yogyakarta: Aditya Media. 